\title{
A relação direito e política: uma análise da atuação do Judiciário na história brasileira
}

\section{The relationship law and politics: an analysis of the performance of the Judiciary in Brazilian history}

\author{
Lenio Luiz Streck* \\ Clarissa Tassinari ${ }^{* *}$ \\ Danilo Pereira Lima**
}

\section{Resumo}

Este artigo pretende analisar a ligação existente entre o modo de compreender a relação Direito e Política e a atuação do Judiciário. Nesse sentido, fazendo uma reconstrução do papel da jurisdição na trajetória do Estado brasileiro, será demonstrado como a Política pode ser um elemento de fragilização do Direito, possibilitando arbitrariedades a partir de sua instrumentalização. Posteriormente, será analisado como o constitucionalismo democrático, inaugurado em 1988, representou mudanças significativas para a compreensão da dinâmica entre o Direito e a Política, observando-se como o Judiciário assimilou essas transformações. Com isso, o que se pretende é problematizar a atuação do Judiciário para a afirmação da autonomia do Direito.

Palavras-chave: Direito. Política. Judiciário. Autonomia do Direito.

Doutor em Direito (UFSC). Pós-Doutor em Direito (FDUL). Procurador de Justiça (TJ-RS). Membro catedrático da Academia Brasileira de Direito Constitucional. Professor titular da Unisinos e Unesa. Professor visitante da Universidade Javeriana de Bogotá, Coimbra e Lisboa (PT). São Leopoldo - SC - Brasil. E-mail: lenios@globo.com

* Doutoranda e Mestre em Direito Público (PPGDireito Unisinos; Bolsista CNPq-Brasil). Bacharel em Direto (Unisinos). Membro do Grupo de Pesquisa "Hermenêutica Jurídica" (CNPq). Membro do Grupo de Pesquisa "Dasein - Núcleo de Estudos Hermenêuticos" (Unisinos). Advogada (OABRS). São Leopoldo - SC - Brasil. E-mail: claunisinos@gmail.com

*** Mestre em Direito Público (PPGDireito Unisinos; Bolsista CNPq). Bacharel em Direito pela Faculdade de Direito de Franca/SP. Membro do Grupo de Pesquisa "Dasein - Núcleo de Estudos Hermenêuticos" (Unisinos). Membro do Grupo "Hermenêutica Jurídica" (CNPq). São Leopoldo SC - Brasil. E-mail: danilolimapt@yahoo.com.br 


\section{Abstract}

This paper analyzes the link between the way we understand the relationship Law and Politics and the role of the judiciary. In this sense, making a reconstruction of the role of the jurisdiction in the trajectory of the Brazilian state, will be shown as the Politics can be an element of fragility of the Law, allowing arbitrary from its instrumentation. Subsequently, it will be analyzed how the democratic constitutionalism, opened in 1988, represented significant changes to the understanding of the dynamics between Law and Politics, observing how the judiciary has assimilated these transformations. Thus, the aim is to discuss the role of the judiciary to the affirmation of the autonomy of law.

Keywords: Law. Politics. Judicial Power. Autonomy of Law.

\section{Introdução}

A trajetória do Estado no Brasil é marcada pela fragilidade que caracteriza o modo de compreender a articulação entre o Direito e a Política. Ao longo dos anos, a criação, o fortalecimento e a realização de direitos e garantias aos cidadãos encontraram entraves devido a uma atuação intrusiva e personalista do Executivo, que colocava seus interesses (políticos) acima dos interesses democráticos, questão que foi radicalizada com a eclosão do regime ditatorial. Desse modo, o campo da Política se tornava imune a um controle jurídico, pois o Direito acabava sendo apenas o instrumento para a legitimidade das decisões políticas, atribuindo uma roupagem de legalidade à vontade dos governantes e ficando com um papel secundário, isto é, materialmente dependente da esfera política, possibilitando, assim, uma atuação arbitrária do Executivo e do Legislativo.

Essa situação se configurou, em parte, pela ausência de um projeto político-jurídico destinado à consolidação de uma democracia em termos materiais, que tem seu ápice com a elaboração de um texto constitucional, o qual, ao se comprometer com os cidadãos pelo estabelecimento de direitos e garantias, acaba colocando limites ao poder político. Entretanto, além disso, é possível observar outro fator que contribuiu para a 
formação desse contexto marcado por uma falta de diferenciação entre Direito e Política: a inexistência de um efetivo controle jurisdicional de constitucionalidade. Em outras palavras, os problemas enfrentados na história brasileira quanto ao modo de compreender a relação entre Direito e Política impediram a consolidação de uma autonomia do âmbito jurídico e foram, em grande parte, facilitados por uma atuação inexpressiva do Judiciário, caudatário, durante muito tempo, do poder político.

Com a promulgação da Constituição de 1988, momento mais importante do processo de redemocratização no Brasil, as funções do Judiciário são redefinidas. Especialmente nos países da América Latina, que passaram por regimes de absoluta restrição de direitos (as ditaduras militares), o fortalecimento de uma efetiva jurisdição constitucional foi um "ato emancipatório" ao Direito. Desse modo, a partir da instauração desse constitucionalismo democrático, Direito e Política passariam a ser compreendidos de modo indissociável, porém diferenciado, mas a atuação do Judiciário, pela via do controle de constitucionalidade, estaria comprometida em possibilitar tal mudança, delimitando, por critérios jurídicos, os limites da Política.

No entanto, não foi isso que ocorreu. Esse fortalecimento do Judiciário acabou gerando, nos termos de Hirschl (2007, p. 1), uma "juristocracia". Com isso, esse autor demonstra que o grau de judicialização no Brasil (e em outros países ${ }^{1}$ ) atingiu a megapolítica - ou a "política pura", como o autor gosta de mencionar (HIRSCHL, 2009, p. 140). Na verdade, a existência ou a intensidade da judicialização da Política (ou de outras dimensões das relações sociais) é a contradição secundária do problema. A grande questão não é o quanto de judicialização, mas como as questões judicializadas devem ser decididas e, nesse ponto, o problema central é a propagação da tese favorável ao

Hirschl (2009) apresenta situações nas quais as decisões, tradicionalmente tomadas pelos meios políticos, acabaram judicializadas, como no caso da eleição norte-americana envolvendo George W. Bush e Al Gore, da decisão do Tribunal Constitucional Alemão sobre o papel da Alemanha na Comunidade Europeia, e do caráter federativo do Canadá. 
ativismo judicial, porque ela permite que, novamente, a Política fragilize o Direito de modo institucionalizado².

Asituaçãoétão delicada que, diante do "agigantamento dos poderes do Judiciário", foi elaborado um Projeto de Emenda Constitucional (PEC 33), que, dentre outras questões, submete ao Congresso Nacional a decisão sobre a inconstitucionalidade de Emendas à Constituição. Diante de tudo isso, a proposta deste artigo é discutir a relação Direito e Política sob a ótica da atuação do Judiciário, fazendo uma análise histórica da relação interinstitucional entre os Poderes antes de 1988 e das transformações ocorridas na atividade jurisdicional pós-Constituição Democrática. Além disso, será demonstrada a importância de se resgatar a autonomia do Direito, a partir de uma defesa da normatividade do texto constitucional, mas também da realização de um controle hermenêutico das decisões judiciais.

A Constituição é o alfa e o ômega da ordem jurídica. Ela oferece os marcos que devem pautar as decisões da comunidade política. Uma ofensa à Constituição por parte do Poder Judiciário sempre é mais grave do que qualquer outra desferida por qualquer dos outros Poderes, porque é ao Judiciário que cabe sua guarda. Desse modo, se este passa a ocupar um papel institucional de maior destaque frente aos demais Poderes, consequentemente, a necessidade de limites à decisão judicial passa a tomar um maior espaço nas discussões públicas. Certamente esse tema é uma questão muito cara ao regime democrático, pois a ausência de controle pode levar ao autoritarismo.

\section{A instrumentalização do Direito por meio do controle político do Poder Judiciário}

Historicamente, o constitucionalismo brasileiro sempre teve grande dificuldade para limitar o exercício do poder político. Um dos elementos que contribuíram para essa situação foi a ausência de um

2 Essa leitura do ativismo judicial pode ser lida nas obras Verdade e Consenso e Hermenêutica Jurídica e(m) Crise, de Lenio Streck (2011). 
Poder Judiciário com autonomia funcional para sustentar a supremacia constitucional. Ademais, as constantes interferências políticas em sua respectiva área de atuação, tanto durante o Império como na maior parte do Período Republicano, impediram a necessária defesa da autonomia do Direito contra governos despóticos e autoritários. Assim, em vez de um poder político submetido à Constituição, o que realmente predominou foi a sobreposição de um domínio estamental contrário ao Direito, corroborado por uma atuação institucional inexpressiva por parte do Poder Judiciário ${ }^{3}$. Essa situação pode ser observada em quatro momentos específicos: no Império, na República Velha, na Ditadura Vargas e na Ditadura Militar de 1964.

No primeiro caso, a Constituição de 1824 foi outorgada pelo imperador D. Pedro I após o fechamento daAssembleia Geral Constituinte e Legislativa pelas tropas imperiais. Antes dessa medida despótica, o monarca já havia alertado os deputados constituintes a aprovarem uma Constituição digna de sua imperial aceitação. Desse modo, ele já anunciava à nação que qualquer tentativa de limitação dos seus poderes monárquicos não seria bem-vinda. Por esse motivo, o pacto constitucional de 1824, elaborado após a dissolução da Assembleia, reconheceu uma liberdade meramente formal com a existência de um Poder Executivo extremamente forte, preexistente ao próprio pacto jurídico-político. Na verdade, o que ocorreu foi uma verdadeira aberração à teoria constitucional, com a soberania popular entregue ao imperador, e não à Assembleia Constituinte (ROCHA, 1995) ${ }^{4}$.

Essa constitucionalização puramente formal procurou ocultar as reais intenções despóticas de D. Pedro I e serviu para impedir reações mais violentas contra um regime político que estava assentado no domínio pessoal. Nesse sentido, a Constituição de 1824 serviu muito mais pelo seu efeito simbólico de legitimação do que propriamente pela

\footnotetext{
3 Aqui, o presente trabalho se inspira em Faoro (2008) para melhor compreender o funcionamento institucional do Estado brasileiro.

4 Nesse mesmo sentido, Rocha (1995, p. 99) afirma que "a monarquia era um sistema que tentava aparentar, formalmente, ser um regime liberal, mas, na realidade, estava fundada numa rígida centralização burocrática e numa economia de exportação calcada na mão de obra escrava".
} 
sua eficácia jurídica. Destituída de qualquer força normativa, o pacto constitucional outorgado pelo imperador foi incapaz de limitar o poder político e impedir o elevado grau de instrumentalização do Direito pelos donos do poder.

É importante destacar que, além de um Poder Judiciário destituído de autonomia funcional, a ausência de uma jurisdição constitucional contribuiu fortemente para o enfraquecimento da Constituição de 1824. O Império se inspirou no constitucionalismo francês para rebaixar o Judiciário a uma posição institucional secundária. Por isso, o Supremo Tribunal de Justiça do Império, reconhecido na época como órgão de cúpula do Poder Judiciário, funcionou somente como Tribunal de Cassação, ficando sua atuação restrita ao Direito Privado e ao Direito Criminal, simplesmente aplicando a lei aos fatos.

A formação de uma monarquia despótica - atuando principalmente por meio do Poder Moderador - e a inexistência de uma jurisdição constitucional contribuíram para que o Poder Judiciário assumisse um papel inexpressivo durante todo o Império. Para agravar ainda mais a situação, o cargo de magistrado não se encontrava estruturado como uma carreira burocrática moderna, voltado para uma atuação independente de qualquer interferência política. Nessa perspectiva, os juízes encontravam-se atrelados ao modo de dominação política formado pelo Império, sendo o ingresso no Poder Judiciário o primeiro passo para uma carreira promissora na Câmara dos Deputados, no Senado e no Conselho de Estado (SLEMIAN, 2010). Assim, em vez de uma atuação institucional mais preocupada com a defesa das liberdades constitucionais, os juízes estavam inteiramente inseridos nas disputas político-partidárias entre os membros das oligarquias imperiais, que se digladiavam por uma posição mais próxima do trono (KOERNER, 1998) $)^{5}$.

A respeito da participação política dos juízes durante o período do Império, Koerner (1998, p. 48) afirma: "Assim a magistratura era a forma privilegiada de ingresso na elite política imperial. A carreira dos magistrados era dirigida para este objetivo e podia assumir caminhos diversos, de caráter judicial, político ou administrativo. A sua situação política era ao mesmo tempo a de representantes do poder imperial, de membros de um partido e, portanto, de aliados ou adversários das facções locais, e de juízes." 
No segundo caso, a ascensão de um novo regime político que em tese deveria romper radicalmente com a estrutura de poder gerada pelo Império - apenas substituiu o despotismo do imperador pelo autoritarismo do presidente da República. A transição ocorreu por meio de um golpe de estado desferido pelos militares e acabou incorporando, apenas pro forma, as instituições elaboradas pelo constitucionalismo estadunidense. A Constituição de 1891 trouxe dos Estados Unidos o presidencialismo, o federalismo e o controle difuso de constitucionalidade. No entanto, a maneira como o estamento se apropriou dessas instituições serviu principalmente para estimular o poder arbitrário do presidente da República. Desse modo, o federalismo foi transformado em um mecanismo de relação oligárquica entre o poder central e as lideranças locais, e o controle difuso acabou por não funcionar sob os mesmos termos estabelecidos pelo judicial review.

No século XIX, a formação dos Estados Unidos exerceu uma influência extremamente importante no constitucionalismo moderno ao favorecer o fortalecimento da doutrina da supremacia constitucional e apresentar instrumentos jurídicos que deveriam evitar tanto as arbitrariedades do Poder Executivo quanto as do Poder Legislativo (FIORAVANTI, 2003). Contudo, na República brasileira, essas questões foram incorporadas de maneira completamente incoerente pelo estamento burocrático. Saiu de cena uma estrutura política comandada do alto pelo imperador e entrou em seu lugar um regime oligárquico, autoritário e excludente, reproduzindo uma situação na qual o Direito continuaria instrumentalizado pelos construtores da "nova ordem política" (BASBAUM, 1975) ${ }^{6}$.

De acordo com Faoro (2008, p. 533), "[o novo regime] continuaria a operar a mesma prática imperial, em que as ficções constitucionais assumem o caráter de um disfarce, para que, à sombra da legitimidade

Por esse motivo, Aristides Lobo afirmou que o povo apenas assistiu de maneira bestializada a marcha militar que destronara D. Pedro II em 15 de novembro de 1889. 
artificialmente montada, se imponham as forças sociais e políticas sem obediência às fórmulas impressas". Assim, reformas que diziam respeito a uma maior garantia dos direitos civis (como a autonomia funcional do Poder Judiciário), à ampliação da participação popular no processo político e ao fim das fraudes eleitorais acabaram relegadas a um segundo plano.

Em um ambiente político tão conturbado como era o da República Velha, com governos que constantemente decretavam estado de sítio para suspender os direitos e as garantias constitucionais do cidadão, o Poder Judiciário acabou encontrando-se de mãos atadas nos momentos em que deveria exercer a defesa da autonomia do Direito. Nessas condições, o Superior Tribunal Federal (STF) - organizado como uma Corte Constitucional pelo novo regime - não alcançou a autonomia funcional necessária para defender as estruturas federativas e democráticas, bem como a preservação das liberdades individuais contra os atos arbitrários do Poder Executivo. Na verdade, a incorporação do controle difuso se deu de maneira frágil e precária, com a adaptação de um importante mecanismo de controle do poder político a uma conjuntura sociopolítica descomprometida com a defesa do précompromisso constitucional (TOMAZ DE OLIVEIRA, 2009).

No terceiro caso, o fim da República Velha não se deu por meio da democratização do Estado brasileiro, mas da imposição de um projeto político autoritário, que, a partir de 1937, passou a flertar diretamente com o totalitarismo nazifascista. Nesse sentido, de acordo com BresserPereira (2012, p. 105), "quando se discute a relação Estado-sociedade, há a clássica questão da primazia. Em geral a sociedade, a nação, precede o Estado. Não foi esse o caso do Brasil". Logicamente, o tratamento dispensado ao Poder Judiciário durante a Ditadura Vargas não poderia ter sido diferente do que já havia ocorrido anteriormente, com um Poder Executivo arbitrário e uma jurisdição constitucional amedrontada pelas constantes ameaças de intervenção política. Desse modo, mais uma vez, o STF acabou impedido de exercer o necessário controle de constitucionalidade dos atos políticos, sendo enquadrado 
pelo Poder Executivo nos momentos em que ousasse discordar dele (VILLA, 2011).

Essa situação se agravou ainda mais a partir da ascensão do Estado Novo, em 1937. Diante de um Poder Judiciário submetido aos desígnios políticos do Poder Executivo, quem realmente ocupou um lugar de destaque no cenário autoritário do regime de exceção foi o Tribunal de Segurança Nacional, por meio das constantes condenações de opositores políticos do regime (CATTONI DE OLIVEIRA; SIQUEIRA, 2012). Essa situação gerou uma vida atribulada ao constitucionalismo brasileiro e fez com que a sociedade sofresse uma modernização controlada e imposta de cima para baixo pelos donos do poder. $\mathrm{Na}$ verdade, a constante instrumentalização do Direito e o controle político do Poder Judiciário impossibilitaram o aparecimento de uma ordem constitucional democrática, baseada na tripartição de Poderes. Nesse sentido, a jurisdição constitucional, presente apenas em seu aspecto formal na Constituição de 1937, deveria ocorrer da seguinte maneira:

Artigo 96: Só por maioria absoluta de votos da totalidade dos seus juízes poderão os tribunais declarar a inconstitucionalidade de lei ou de ato do presidente da República. Parágrafo único - No caso de ser declarada a inconstitucionalidade de uma lei que, a juízo do presidente da República, seja necessária ao bem-estar do povo, à promoção ou defesa de interesse nacional de alta monta, poderá o presidente da República submetê-la novamente ao exame do Parlamento: se este a confirmar por dois terços de votos em cada uma das Câmaras, ficará sem efeito a decisão do tribunal.

$\mathrm{Na}$ prática, isso acabou com o controle de constitucionalidade durante o Estado Novo, pois quem realmente estava incumbido de dar a última palavra sobre a Constituição era o presidente da República.

No quarto e último caso, a Ditadura Militar de 1964 rompeu com o pacto constitucional estabelecido em 1946 e deu início a mais um regime de exceção na história política do Brasil. Segundo Severo Rocha (1997), tratou-se de um período caracterizado por um Direito 
constitucional não constitucional, pois a proteção jurídica do cidadão se transformou em mera retórica pelo regime de exceção. Foi uma espécie de constitucionalismo antiliberal, afinal, a suspensão dos direitos fundamentais foi autorizada por um Pseudodireito (SANTOS, 2007). Desse modo, os golpistas mantiveram apenas um verniz de legalidade para seus atos arbitrários, cerceando a autonomia funcional do Poder Judiciário através das chamadas cláusulas de exclusão da apreciação judicial, por exemplo.

O controle político do Poder Judiciário não se restringiu somente a esse ponto. Juntamente com ele veio a aposentadoria compulsória de três ministros do STF contrários aos atos arbitrários praticados pelo Poder Executivo, como foi o caso dos afastamentos de Evandro Lins e Silva, Hermes Lima e Victor Nunes Leal. Ao mesmo tempo, para manter o domínio sobre a Corte Constitucional, foram indicados ministros mais alinhados com o Poder Executivo. Nesse sentido, o Estado burocráticoautoritário fragilizou os limites impostos pelo Direito ao exercício arbitrário do poder político, abalando a necessária autonomia funcional do Poder Judiciário.

Foi nesse contexto que, paradoxalmente, o Brasil recepcionou o controle concentrado de constitucionalidade estabelecido na Europa continental após a Segunda Guerra Mundial. Na experiência europeia, a jurisdição constitucional mostrou-se necessária para garantir a supremacia das novas Constituições e, simultaneamente, defender a autonomia do Direito. Contudo, a incorporação feita pelo Brasil durante a Ditadura Militar serviu somente para aumentar o domínio do Poder Executivo sobre o Poder Judiciário. Na verdade, a real intenção do Regime Militar foi estabelecer um mecanismo rápido e eficaz de controle da atividade judicial e impedir que juízes com posturas ideológicas divergentes pudessem contrariar o Poder Executivo. Assim, ficou estabelecido o modelo abstrato de controle de constitucionalidade sob a forma de uma representação, que haveria de ser proposta exclusivamente pelo procurador-geral da República, na época cargo de confiança do Poder Executivo.

Nesse sentido, é possível afirmar que as intervenções do Executivo sobre a atuação do Poder Judiciário prejudicou o fortalecimento de 
uma jurisdição constitucional no contexto brasileiro, contribuindo para que o Direito não alcançasse a autonomia necessária para limitar o exercício do poder político. A ineficiência de mecanismos explícitos de responsabilização constitucional dos governantes em relação aos governados fez predominar a existência de regimes autoritários por um longo tempo. Desse modo, em vez de um poder político submetido à Constituição, o que realmente ocorreu foi a sobreposição de um domínio estamental contrário ao Direito, dificultando a incorporação das conquistas constitucionais que poderiam favorecer a institucionalização do regime democrático.

\section{A Constituição de 1988 e a ruptura com o autoritarismo político}

A história brasileira demonstra que a caracterização de um Poder Judiciário cuja atuação seja atravessada por qualquer espécie de controle político exercido pelos demais Poderes implica, necessariamente, a inexistência de um efetivo controle jurisdicional de constitucionalidade. Como é possível perceber, no passado, as constantes intervenções no Judiciário contribuíram para que o Direito perdesse sua autonomia e o poder político passasse a ser exercido de maneira completamente arbitrária por aqueles que comandavam o Estado. Certamente, o controle político do Poder Judiciário foi capaz de sufocar, durante muito tempo, a atuação da jurisdição constitucional no contexto brasileiro, prejudicando a incorporação do controle difuso e do controle concentrado de constitucionalidade.

Após 24 anos de Ditadura Militar, a promulgação da Constituição de 1988 alterou significativamente o quadro institucional brasileiro. Se nos regimes políticos anteriores o Direito estava ao alcance do poder político, sendo manipulado conforme o alvedrio de seus governantes, a partir do novo paradigma constitucional, foi atribuído um papel estratégico ao Poder Judiciário (conferindo-Ihe autonomia funcional), com o intuito de impedir que o Direito continuasse a ser instrumentalizado. A transição para o Estado Democrático de Direito aumentou o controle 
dos atos políticos, transferindo ao STF o papel institucional de guardião da Constituição. Assim, o Direito, especialmente a partir do conteúdo que passou a lhe constituir através da promulgação da Constituição de 1988 (com a incorporação de princípios e direitos fundamentais), ganha o condão de se sobrepor tanto às decisões políticas tomadas pelo Poder Executivo quanto às decisões majoritárias tomadas pelo Parlamento, afinal, existe uma legalidade (constitucional) vinculante que deve ser respeitada. Para isso, a atuação da jurisdição constitucional é fundamental.

Afirmar a importância do exercício da jurisdição constitucional implica um fortalecimento da democracia, que, antes de 1988, era inexistente ou possuía apenas um caráter "burocrático" de organização institucional. Majoritariamente, a doutrina estrangeira trata o constitucionalismo no Brasil a partir de um enfoque que, muitas vezes, a Teoria do Direito brasileira parece esquecer - de que o Brasil está incluído entre os países considerados e chamados de "novas democracias"7. Nesse contexto, a expressão "novas democracias" pode ser entendida sob dois aspectos: primeiro, por se tratar de países que apenas há poucos anos conseguiram afirmar um regime constitucionalmente democrático, isto é, por constituírem jovens democracias; segundo, por fazer referência a um novo modo de compreender a democracia, especificamente porque, no interior desse movimento democratizante, passa a ser agregado um elemento que até então, na história desses países, não havia tido tanta importância como no atual contexto: o papel do Judiciário na concretização dos direitos.

Gloppen, Gargarella e Skaar (2004), na introdução do livro que organizaram para discutir a função dos tribunais nesses países de democracia recente, afirmam que as Cortes exercem uma atribuição

7 Esse enfoque é dado por Hirschl (2007), afirmando que o fenômeno abrangente da judicialização tem como origem, dentre outros contextos, a transição de um quase democrático ou autoritário regime para a democracia, caso das mais recentes democracias no sul da Europa (Grécia, Portugal, Espanha) e na América Latina, que adotaram direitos fundamentais como parte de sua Constituição, bem como estabeleceram alguma forma de um ativo controle de constitucionalidade. 
fundamental para a consolidação dos regimes democráticos, na medida em que garantem a proteção aos direitos humanos, reforçam o pacto constitucional, bem como são responsáveis por tornar os detentores do poder responsáveis (accountables) pela manutenção das regras (democráticas) do jogo. Entretanto, ao mesmo tempo em que declaram isso logo na abertura de sua obra, os autores também questionam: há uma conexão entre o estabelecimento dessas metas e o que realmente acontece?

Para eles, o papel central das Cortes no contexto das "novas democracias" é assegurar a prestação de contas do exercício do poder político (como referido na obra, "making political power-holders accountables"). Essa ideia de "prestação de contas" (accountability) está fundamentada em três premissas fundamentais: garantir a transparência ("transparency"), assegurar a justificação dos atos de poder de acordo com as regras ("answerability") e exercer o controle aos atos de governo, impondo freios às medidas inconstitucionais que violem os direitos básicos ou comprometam a democracia ("controllability"). Tudo isso se revela extremamente relevante, considerando-se a trajetória e o desenvolvimento do Estado Democrático de Direito, pois, como referido, a América Latina contou com experiências que colocaram o Poder Executivo acima de tudo (dos demais Poderes e dos direitos que até então haviam sido conquistados), sendo determinante para que, passado esse momento, fosse dado ao Judiciário, especialmente ao controle de constitucionalidade, a função de evitar os atos de arbitrariedade dos demais Poderes, transformando a jurisdição, em certo sentido, no centro da retomada democrática (GLOPPEN; GARGARELLA; SAKAAR, 2004).

Ocorre que a ausência de um controle jurídico (constitucional) sobre o âmbito político e a defesa do ativismo judicial se equivalem, pois em ambos os casos não há uma preocupação com a premissa democrática. Ou seja, há apenas um deslocamento da vontade: se antes de 1988, com o Judiciário enfraquecido, prevalecia a vontade (arbitrária) do Executivo, a partir de 1988, por um desvio do que está previsto na Constituição, passa a valer a vontade (discricionária) dos 
juízes, os quais, muitas vezes, decidem por critérios políticos. Volta-se, portanto, ao grande dilema da relação Direito e Política.

Essa ideia da aposta de um papel protagonista da jurisdição e a promulgação da tese favorável ao ativismo judicial costuma ser fundamentada a partir da experiência norte-americana e da função exercida pelo judicial review. De fato, o ativismo judicial nasceu nos Estados Unidos, onde se discute a legitimidade do controle de constitucionalidade há mais de 200 anos. O problema é que, na dificuldade em distingui-lo do fenômeno da judicialização da Política ${ }^{8}$, o Direito brasileiro, por parcela significativa de seus juristas e juízes, acabou incorporando, de modo equivocado, como sinônimo de algo positivo ("uma intervenção do Judiciário para o bem"). O que não se leva em consideração é que, no contexto estadunidense, foi possível visualizar a incidência de um ativismo judicial pela via da postura conservadora; basta que se observe a postura da Suprema Corte estadunidense em relação ao New Deal, que, aferrada aos postulados de um liberalismo econômico do tipo laissez-faire, barrava, por inconstitucionalidade, as medidas intervencionistas estabelecidas pelo governo Roosevelt (WOLFE, 1994).

Para desmistificar essa ideia de que nos Estados Unidos prevalece um posicionamento favorável ao protagonismo do Judiciário, Shapiro (2004), cientista político estadunidense, possui uma posição desconfiada quanto a atribuir tamanha responsabilidade às Cortes. De acordo com ele, nem mesmo na Inglaterra e nos Estados Unidos, isto é, nos países que deram origem a esse sistema de controle judicial, foi possível tornar o Judiciário um espaço de consolidação democrática e justiça social. Assim, considerando que os países latino-americanos, em decorrência dos acontecimentos históricos pelos quais passaram, possuem um vazio

Há uma grande diferença entre o fenômeno da judicialização da Política e o ativismo judicial: o primeiro é decorrente de um contexto social, ao passo que o segundo é gestado dentro da própria sistemática jurídica, consolidando um desvio na atuação do Judiciário (TASSINARI, 2013). Por esse motivo, é possível dizer que a judicialização da política é contigencial; o ativismo judicial, ao contrário, é uma postura do Judiciário, que passa a decidir por convicções pessoais (STRECK, 2011). 
no preenchimento das condições sociais e políticas prévias sobre as quais as nações que deram origem ao controle de constitucionalidade fundaram a legitimidade dessa instituição, ele não é otimista em relação a essa consolidação de uma jurisdição (constitucional) forte ${ }^{9}$.

Como se pode perceber, a problematização dos poderes que possuem juízes e tribunais passa diretamente pela questão da autonomia (política) do Judiciário, o que, no fundo, reflete o modo como é articulada a relação Direito e Política. Evidentemente, em face da experiência vivenciada pelo Brasil, na qual o Poder Judiciário se demonstrou muitas vezes inexpressivo ou instrumento da realização de desígnios dos demais Poderes (em especial, do Executivo), garantir e assentar o papel autônomo do Judiciário é um relevante passo na construção da democracia. Contudo, como afirma Santiso (2004), o caso brasileiro demonstra que o excessivo apego a essa autonomia pode acabar repercutindo em uma falta de accountability, transformando o Poder Judiciário em um Poder acima da lei.

\section{A necessária defesa da autonomia do Direito}

A predominância institucional do Poder Judiciário na atual quadra da história não implica uma atuação ativista por parte dos magistrados. O constitucionalismo contemporâneo não dá margem a nenhum tipo de discricionariedade judicial. Conceder aos juízes o poder de livre atribuição sobre o Direito deve ser considerado uma postura autoritária, capaz de acarretar graves prejuízos ao regime democrático. Desse modo, a atuação do Judiciário deve ser limitada não por meio de um controle político de seus atos normativos, mas por um controle hermenêutico. Isso é fundamental para quem continua compreendendo o constitucionalismo

9 "In the realm of constitutional judicial review, the question addressed here is success. How and when have constitutional courts succeeded? Success will be defined narrowly and positivistically in terms of when an exercise of constitutional judicial review has changed public policy in the direction the court wants public policy to go. Obviously implicit in this definition of success is the precondition that the court manages to establish and retain its power to exercise judicial review. What it does not contain is any substantive component such as changing public policy in a direction more favorable to 'human rights' or 'social justice"' (SHAPIRO, 2004, p. 5). 
como uma técnica de limitação do poder, trabalhando sempre sob uma perspectiva de defesa da autonomia do Direito frente às constantes investidas do poder político.

O constitucionalismo contemporâneo aposta na autonomia do Direito para delimitar a transformação das relações jurídico-institucionais, protegendo-as do constante perigo das arbitrariedades políticas. Desse modo, a defesa de um efetivo controle hermenêutico das decisões judiciais a partir do respeito à autonomia do Direito não quer dizer que, por vezes, não seja aconselhável e necessária uma atuação propositiva do Poder Judiciário. Na verdade, uma atuação mais destacada do Judiciário - no sentido em que propõe o Estado Democrático de Direito - não pode ser confundida com decisionismos e atitudes pragmatistas favoráveis ao ativismo judicial.

Em um regime democrático, o magistrado faz escolhas apenas em sua vida privada; já no âmbito do Poder Judiciário, suas decisões devem lançar argumentos de integridade e coerência, que emanam da própria comunidade política. É preciso compreender que a redefinição do papel exercido pelo Poder Judiciário não elevou sua posição institucional a uma atuação totalmente arbitrária, livre de qualquer controle democrático. Portanto, impedir a manifestação de ativismos judiciais contribui para a institucionalização de uma verdadeira blindagem contra os predadores da autonomia do Direito.

Em todos os momentos históricos que o Direito esteve à disposição do poder político, para ser suspendido ou aplicado conforme a vontade de uma autoridade política, o constitucionalismo teve grande dificuldade para exercer sua supremacia. A partir do "encurtamento" do espaço de manobra e conformação do legislador e do consequente aumento da proteção contra maiorias (eventuais ou não) - cerne do contramajoritarismo -, parece evidente a necessidade da implementação de mecanismos de controle daquilo que é o repositório do deslocamento do polo de tensão da legislação para a jurisdição: as decisões judiciais. Em outras palavras, a autonomia do Direito e a sua umbilical ligação com a dicotomia "democracia/constitucionalismo" exigem da Teoria do Direito e da Constituição uma reflexão de cunho hermenêutico. 
Como afirma Dworkin (2002), a justificativa mais geral e abrangente para o Direito é política. Nos termos da doutrina da responsabilidade política, os juízes têm para si o dever de, no momento da decisão judicial, decidir conforme o Direito, segundo argumentos de princípios, e não de política.

Por esse motivo é necessário o desenvolvimento de uma Teoria da Decisão Judicial. Esse é o projeto da Teoria do Direito contemporânea, que responde à necessidade de se construir anteparos para a autoridade judicante, na perspectiva de tornar mais democrático o Poder Judiciário. Nesse sentido, o "controle" das decisões se opera hermeneuticamente. Aquele que interpreta deve (de)mo(n)strar que sua construção é a melhor segundo o Direito da comunidade política. Aqueles que são destinatários da interpretação, por sua vez, têm o dever de questionála, apontando os fracos argumentos e as construções mal alicerçadas. Outro ponto absolutamente fundamental desse controle hermenêutico das decisões é a exigência de que elas sejam proferidas de forma consistente, segundo critérios de integridade da jurisprudência. Afinal, como é possível que um tribunal negue, sem utilizar uma argumentação constitucional, a validade de uma lei votada democraticamente? Tratase de uma exigência de equanimidade (fairness, como quer Dworkin), a fim de que todos os cidadãos recebam tratamento igualitário quando buscarem a tutela jurisdicional.

\section{Conclusão}

Os gregos inventaram a democracia. E também inventaram a autonomia do Direito. O primeiro tribunal está lá na Oresteia. Agamenon é assassinado na banheira pelo amante de sua mulher, Clitenestra (na volta de Troia, 10 anos depois). Orestes, o filho desterrado de Agamenon, atiçado pelo deus Apolo, é induzido à vingança. Ele deveria matar sua mãe (Clitenestra) e o amante dela, Egisto. Orestes mata os dois. Aí vem a culpa. Ele é assaltado pela anoia, a loucura que acomete quem mata a própria gente. Ao assassinar sua mãe, Orestes desencadeia a fúria das Erínias, que eram divindades das profundezas ctônicas (eram 
três: Alepho, Tisífone e Megera). Apavorado, Orestes implora o apoio de Apolo. Pede um julgamento. Constitui-se, assim, o primeiro tribunal, cuja função era parar com as mortes de vingança. Corifeu, líder do coro, foi o acusador. Apolo, o defensor. Orestes reconheceu a autoria, mas invoca a determinação de Apolo. Os votos dos jurados, depositados em uma urna, dão empate: 5 a 5. Palas Atena desempata, com o voto de Minerva (in dubio pro reo). Rompe-se um ciclo. Acabam-se as vinganças. É uma antevisão da modernidade.

Assim, ao analisar a difícil relação entre o Direito e a Política, é possível demonstrar a importância da autonomia funcional do Poder Judiciário para a defesa da supremacia constitucional, destacando que a não interferência da Política nas decisões judiciais é um elemento imprescindível para o fortalecimento das novas democracias. Sem dúvida alguma, a jurisdição constitucional cumpre um papel fundamental no Estado Democrático de Direito, ao impedir que manifestações autoritárias por parte do poder político possam prejudicar a autonomia do Direito. Desse modo, essa inovação institucional deve ser encarada como uma conquista do constitucionalismo contemporâneo, que, após a Segunda Guerra Mundial, concedeu maior destaque à atuação do Poder Judiciário.

No contexto brasileiro, essas conquistas foram incorporadas tardiamente, prejudicando a institucionalização do regime democrático. Do Império à República, ocorreram diversas ações arbitrárias por parte do poder político que deixaram o Estado à mercê de governos personalistas pouco preocupados com as determinações constitucionais. Diante de condições institucionais adversas, o Poder Judiciário acabou exercendo um papel inexpressivo durante a maior parte da história do constitucionalismo brasileiro, sendo submetido constantemente ao mandonismo político exercido no âmbito do Poder Executivo.

Essa situação teve início logo após o processo de independência, quando o despotismo monárquico assumiu o controle do Estado e teve continuidade mesmo depois da proclamação da República, devido à ascensão do autoritarismo presidencialista. Em todos esses períodos 
históricos, o Poder Judiciário foi invadido pelo poder político, causando um enorme prejuízo para a defesa da autonomia do Direito. Dessa forma, defender a supremacia constitucional durante esses momentos foi uma tarefa praticamente impossível. Primeiramente, porque, no Império, não havia jurisdição constitucional e o monarca governava despoticamente, por meio do Poder Moderador; em segundo lugar, porque, na República, a incorporação do controle de constitucionalidade ocorreu apenas formalmente, nos momentos de grave crise institucional.

Acondição inexpressiva em que o Poder Judiciário se encontrava foi superada somente a partir da Constituição de 1988, com a reorganização dos Poderes e o fortalecimento da jurisdição constitucional. No entanto, esse deslocamento do centro de decisões do Legislativo e do Executivo para o Judiciário não deve ser encarado como uma abertura para posições ativistas.

Uma maior atuação do Poder Judiciário exige um aumento significativo da responsabilidade política de quem exerce a função pública de magistrado. Se, no passado, o personalismo do poder político fragilizou as Constituições anteriores, hodiernamente, o personalismo judicial também pode prejudicar a nova Constituição. É por esse motivo que o presente artigo sustenta a necessidade de um maior controle das decisões judiciais - não para retornar ao velho controle político do Poder Judiciário, que no passado trouxe tantos prejuízos para o constitucionalismo brasileiro, mas para um controle hermenêutico dos atos judiciais, adequado ao atual estágio do constitucionalismo democrático.

Portanto, a autonomia do Direito necessita de um Poder Judiciário independente, capaz de exercer sua função institucional sem qualquer interferência da Política. Qualquer espécie de controle político dos atos judiciais pode acarretar um grave retrocesso institucional para o regime democrático. A independência do Poder Judiciário é uma conquista democrática. Parece óbvio, mas há que se comunicar esse óbvio no atual estágio do constitucionalismo. Conquista, sim, porque não foi resultado de uma autorização cartorial. Por muitos anos, a sociedade brasileira 
lutou para construir os mecanismos de limitação de poder com os quais hoje estamos habituados. Para se enfrentar os perigos de um governo dos juízes ou de uma juristocracia, é necessário uma consistente Teoria do Direito e agentes jurídicos aptos a trabalharem na construção de bons argumentos e na desconstrução dos argumentos ruins.

\section{Referências}

BASBAUM, Leôncio. História sincera da República: de 1889 a 1930. São Paulo: Alfa-Omega, 1975.

BRESSER-PEREIRA, Luiz Carlos. Brasil, sociedade nacionaldependente. Novos Estudos Cebrap, São Paulo, n. 93, p. 101-121, 2012.

CATTONI DE OLIVEIRA, Marcelo Andrade; SIQUEIRA, Gustavo Silveira. Pequeno ensaio sobre a injustiça: memórias secas de um tribunal de segurança nacional. Sequência, Florianópolis, v. 61, p. 111-125, 2012.

DWORKIN, Ronald. Levando os direitos a sério. Tradução de Nelson Boeira. São Paulo: Martins Fontes, 2002.

FAORO, Raymundo. Os donos do poder: formação do patronato político brasileiro. 4. ed. São Paulo: Globo, 2008.

FIORAVANTI, Maurizio. Los derechos fundamentales: apuntes de historia de las constituciones. Madrid: Trotta, 2003.

GLOPPEN, Siri; GARGARELLA, Roberto; SAKAAR, Elin (Ed.). Democratization and the judiciary: the accountability functions of courts in new democracies. London: Frank Cass, 2004.

HIRSCHL, Ran. O novo constitucionalismo e a judicialização da política pura no mundo. Revista de Direito Administrativo, Rio de Janeiro, v. 251, p. 139-178, maio/ago. 2009.

Towards juristocracy: the origins and consequences of the new constitutionalism. Cambridge: Harvard University Press, 2007.

KOERNER, Andrei. Judiciário e cidadania na Constituição da república brasileira. São Paulo: Hucitec, 1998. 
ROCHA, Leonel Severo. A democracia em Rui Barbosa: o projeto político liberal-racional. Rio de Janeiro: Liber Juris, 1995.

A especificidade simbólica de direito brasileiro pós-revolução de 1964. In: OLIVEIRA JUNIOR, José Alcebíades de (Org.). O novo em direito e política. Porto Alegre: Livraria do Advogado, 1997. p. 77-87.

SANTISO, Carlos. Economic reform and judicial governance in Brazil: balancing independence with accountability. In: GLOPPEN, Siri; GARGARELLA, Roberto; SAKAAR, Elin (Ed.). Democratization and the judiciary: the accountability functions of courts in new democracies. London: Frank Cass, 2004. p. 117-131.

SANTOS, Rogério Dultra dos. Francisco Campos e os fundamentos do constitucionalismo antiliberal no Brasil. Dados, Rio de Janeiro, v. 50, n. 2, p. 281-323, 2007.

SHAPIRO, Martin. The success of judicial review: the United States' experience. In: GLOPPEN, Siri; GARGARELLA, Roberto; SAKAAR, Elin (Ed.). Democratization and the judiciary: the accountability functions of courts in new democracies. London: Frank Cass, 2004. p. 5-18.

SLEMIAN, Andréa. O Supremo Tribunal de Justiça nos primórdios do Império do Brasil (1828-1841). In: LOPES, José Reinaldo de Lima (Org.). O Supremo Tribunal de Justiça do Império: 1828-889. São Paulo: Saraiva, 2010. p. 19-61.

STRECK, Lenio Luiz. Hermenêutica jurídica $\mathbf{e}(\mathbf{m})$ crise: uma exploração hermenêutica do direito. 10. ed. Porto Alegre: Livraria do Advogado, 2011.

. Verdade e consenso: Constituição, hermenêutica e teorias discursivas. 4. ed. São Paulo: Livraria do Advogado, 2011.

TASSINARI, Clarissa. Juris dição e ativismo judicial: limites da atuação do judiciário. Porto Alegre: Livraria do Advogado, 2013.

TOMAZ DE OLIVEIRA, Rafael. A Constituição e o estamento: contribuições à patogênese do controle difuso de constitucionalidade brasileiro. In: BARRETO, Vicente de Paulo; CULLETON, Alfredo Santiago; STRECK, Lenio Luiz (Org.). 20 anos de Constituição: os 
direitos humanos entre a norma e a política. São Leopoldo: Oikos, 2009. p. 215-240.

VILLA, Marco Antonio. A história das Constituições brasileiras. São Paulo: Leya, 2011.

WOLFE, Christopher. The rise of modern judicial review: from constitutional interpretation to judge-made law. Boston: Littlefield Adams Quality Paperbacks, 1994.

Recebido em: 06/05/13

Aprovado em: 13/11/13 